Natarajan Karthiga ${ }^{1}$, James Maria Praveena', Ashokan

Eazhisai Monisha', Balamurugan Gomathi', Maria Louis

Helan Celia', Bose Hemalatha', Thiruppathi Raja

Umasankareswari', LJerald Majellah ${ }^{3}$, Susai Rajendran ${ }^{1 *}$

${ }^{1}$ Corrosion Research Centre, Department of Chemistry, St Antony's

College of Arts and Sciences for Women, Dindigul, India

2Department of Chemistry, Rajapalayam Raju's College, Rajapalayam, India

${ }^{3}$ Velammal Medical College Hospital \& Research Institute, Anuppanadi Near Chinthamani, Madurai, Tamil Nadu, India
Short communication

ISSN 0351-9465, E-ISSN 2466-2585

UDC: $(669.057+616-74): 544.653$

doi: $10.5937 /$ zasmat $2003251 \mathrm{~K}$

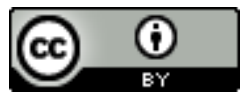

Zastita Materijala 61 (3)

$251-258(2020)$

\title{
Corrosion resistance of orthodontic wire made of SS 316L alloy in artificial saliva in the presence of amlodipine tablet by electrochemical studies
}

\begin{abstract}
The corrosion resistance of SS 316L alloy in artificial saliva, in the absence and presence of Amlodiphine-2.5 $\mathrm{mg}$ has been evaluated by polarization study and AC impedance spectra. Polarisation study reveals that in the presence of Amlodipine-2.5 $\mathrm{mg}$, LPR value increases and corrosion current decreases. In presence of Amlodipine-2.5 mg mg, the corrosion resistance of SS $316 \mathrm{~L}$ alloy in artificial saliva increases. AC impedance study reveals that in the presence of Amlodipine-2.5 mg, $R_{t}$ value increases and $C_{d l}$ decreases. In the presence of Amlodipine-2.5 $\mathrm{mg}$ the corrosion resistance of SS 316L alloy in AS increases. From the present study it is concluded that people clipped with orthodontic wire made of SS $316 \mathrm{~L}$ alloy need not hesitate to take Amlodipine-2.5 mg orally.
\end{abstract}

Keywords: SS 316L alloy, Amlodipine-2.5 mg, electrochemical studies, artificial saliva

\section{INTRODUCTION}

Corrosion resistance of various metals and alloys in artificial saliva in the presence and absence of various tablets, food additives etc have been investigated. Metals and alloys such as Titanium Alloy, stainless steel, SS 316L have been studied [1-10]. El Kouifat et al. have investigated the fretting-corrosion of orthodontic arch-wire/ bracket contacts in saliva environment. The combined effect of fretting and corrosion tests conducted in artificial saliva show that nickel titanium wire is more resistant than stainless steel wire in contact with stainless steel brackets after 100000 cycles. Also, the corrosion resistance in acidified saliva is very pronounced for stainless steel wire and bracket as it reported by many authors. The degradation of the orthodontics materials in the oral environment can cause major problems for the patient's health [11].

\footnotetext{
${ }^{*}$ Corresponding author: Susai Rajendran

E-mail: susairajendran@gmail.com

Paper received: 10. 04. 2020.

Paper corrected: 24.05.2020.

Paper accepted: 02. 06. 2020.

Paper is available on the website: www.idk.org.rs/journal
}

Corrosion inhibition of metals and alloys in saliva environment in presence of inhibitors has been studied by many researchers. Osak et al have examined EIS study of the interfacial properties of the Nitinol electrode oxide layer saliva solution system revealed the capacitive behavior of the material with high corrosion resistance. EIS allowed to determine the resistance of charge transfer through the oxide electrolyte interface. It was found that kinetics of pitting corrosion of the Nitinol electrode in saliva increases with the rising content of Eludril mouthwash [12].

Nanjundan et al. have studied that when acidic food substances are used during fixed orthodontic treatment. Further, in vivo studies are required to analyze the clinical effect of acidic mediums in the oral environment during orthodontic treatment [13].

Gölz et al. have inferred that self-ligating orthodontic appliances may affect salivary $\mathrm{Ni}^{2+}$ concentrations in vivo over the short term. However, levels resembled those documented in conjunction with conventional bracket use and remained below the daily dietary $\mathrm{Ni}$ intake [14]. 


\section{MATERIALS AND METHODS}

\section{Preparation of the metal specimens}

A thin wire metal specimen namely SS $316 \mathrm{~L}$ alloy is utilized as test material for this work. The chemical composition of the alloy is as follows:

$18 \% \mathrm{Cr}, 12 \% \mathrm{Ni}, 2.5 \% \mathrm{Mo}, \mathrm{C}<0.03 \%$, and balance is $\mathrm{Fe}$.

\section{Procedure}

The orthodontic wire was encapsulated in Teflon rod. Prior to the surface treatment, the specimens were subjected to surface polishing. They were degreased with trichloroethylene followed by mechanical polishing with different polishing papers (Course, Medium, Fine \& Extra fine). The specimens were rinsed with ethanol followed by distilled water and dried with a clean tissue paper. Finally the specimens were kept in desiccators until use.

\section{Preparation of artificial saliva}

The corrosion resistance of orthodontic wire made of SS 316L alloy in artificial saliva (AS) was measured in the absence and presence of the tablet. The preparation of artificial saliva was done using the composition of Fusayama Meyer artificial saliva (AS). Artificial saliva was prepared in laboratory and the composition of artificial saliva was as follows:
$\mathrm{KCl}-0.4 \mathrm{~g} / \mathrm{lit}, \mathrm{NaCl}-0.4 \mathrm{~g} / \mathrm{lit}, \mathrm{CaCl}_{2} .2 \mathrm{H}_{2} \mathrm{O}-0.906$ g/lit, $\mathrm{NaH}_{2} \mathrm{PO}_{4} .2 \mathrm{H}_{2} \mathrm{O}-0.690$ g/lit, $\mathrm{Na}_{2} \mathrm{~S} .9 \mathrm{H}_{2} \mathrm{O}$ $0.005 \mathrm{~g} / \mathrm{lit}$, urea $-1 \mathrm{~g} / \mathrm{lit}$.

\section{Amlodipine $-2.5 \mathrm{mg}$}

Amlodipine is used to lower the blood pressure. It can be used alone or in combination with other heart medicines. It is used to help blood flow more easily to your heart when the arteries in your heart are blocked. It is also used to treat coronary artery disease and angina (chest pain) [15].

\section{Potentiodynamic polarization study}

Electochemical studies were carried out in a $\mathrm{CHI}$ Electrochemical work station/ analyzer, model $660 \mathrm{~A}$

The experiments were carried out at average body temperature of $37 \pm 1^{\circ} \mathrm{C}$.

Polarization study was carried out using a three electrodes cell assembly (Scheme 1).SS 316 L was used as working electrode, platinum as counter electrode and saturated calomel electrode (SCE) as reference electrode. After having done iR compensation, polarization study was carried out at a sweep rate of $0.01 \mathrm{~V} / \mathrm{Sec}$. The corrosion parameters such as linear polarization resistance (LPR), corrosion potential $\mathrm{E}_{\text {corr, corrosion current }}$ $\mathrm{I}_{\text {corr }}$ and Tafel slopes $\left(\mathrm{b}_{\mathrm{a}}\right.$ and $\left.\mathrm{b}_{\mathrm{c}}\right)$ were measured.

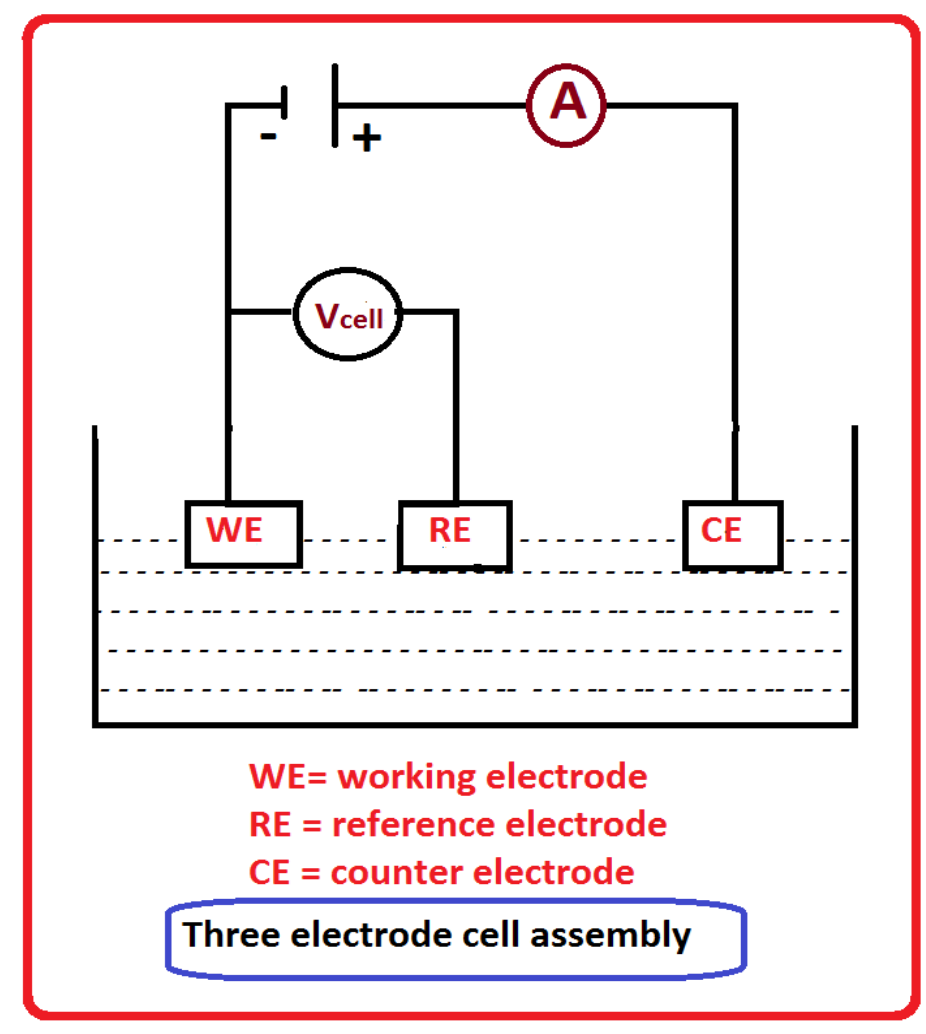

Scheme 1. Three electrode cell assembly

Shema 1. Celija sa tri elektrode 


\section{Alternating current impedance spectra}

$A C$ impedance spectra were recorded in the same instrument used for polarization study, using the same type of three electrode cell assembly. The real part ( $\left.Z^{\prime}\right)$ and imaginary part (Z") of the cell impedance were measured in ohms for various frequencies. The charge transfer resistance $\left(R_{t}\right)$ and double layer capacitance $\left(C_{d l}\right)$ values were calculated.

$\mathrm{C}_{\mathrm{dl}}$ values were calculated using the following relationship.

$$
\begin{aligned}
& R_{t}=\left(R_{s}+R_{t}\right)-R_{s} \\
& C_{d l}=1 / 2 \times 3.14 \times R_{t} \times f_{\text {max }}
\end{aligned}
$$

Where $R_{s}$ is the solution resistance and $f_{\max }$ is the frequency at maximum imaginary impedance.

\section{RESULTS AND DISCUSSION}

Influence of Amlodipine-2.5 mg on SS 316L alloy

Analysis of potentiodynamic polarization study

Electrochemical studies such as polarisation study and $A C$ impedance spectra have been widely used in corrosion controlling studies [16-21].

Corrosion resistance of SS316L alloy in artificial saliva in presence of Amlodipine-2.5 mg is given in the Table 1. The polarization curves of SS $316 \mathrm{~L}$ alloy immersed in various test solutions are shown in Figure 1 and Figure 2.The Linear polarization resistance value of SS 316L in artificial saliva in the absence and presence of Amlodipine$2.5 \mathrm{mg}$ tablet is compared in Table 1 and graphically in Figure 3.

Table 1. Corrosion parameters of SS 316L alloy immersed in Artificial Saliva (AS) in the absence and presence of Amlodipine-2.5 mg obtained by polarization study

Tabela 1. Parametri korozije legure SS 316L uronjeni u veštačku pljuvačku (AS) u odsustvu i prisustvu Amlodipina-2,5 mg dobijenog postupkom polarizacije

\begin{tabular}{|c|c|c|c|c|c|}
\hline System & $\begin{array}{c}E_{\text {corr }} \\
V_{\text {SCE }}\end{array}$ & $\begin{array}{c}b_{c} \\
\text { V/decade }\end{array}$ & $\begin{array}{c}b_{a} \\
\text { V/decade }\end{array}$ & $\begin{array}{c}\text { LPR } \\
\text { Ohmcm }^{2}\end{array}$ & $\begin{array}{c}I_{\text {corr }} \\
A / \mathrm{cm}^{2}\end{array}$ \\
\hline Artificial Saliva & -0.483 & 6.143 & 3.667 & 1973954 & $2.245 \times 10^{-8}$ \\
\hline AS + Amlodipine $-2.5 \mathrm{mg}(250 \mathrm{ppm})$ & -0.456 & 5.835 & 3.615 & 2100809 & $2.190 \times 10^{-8}$ \\
\hline
\end{tabular}

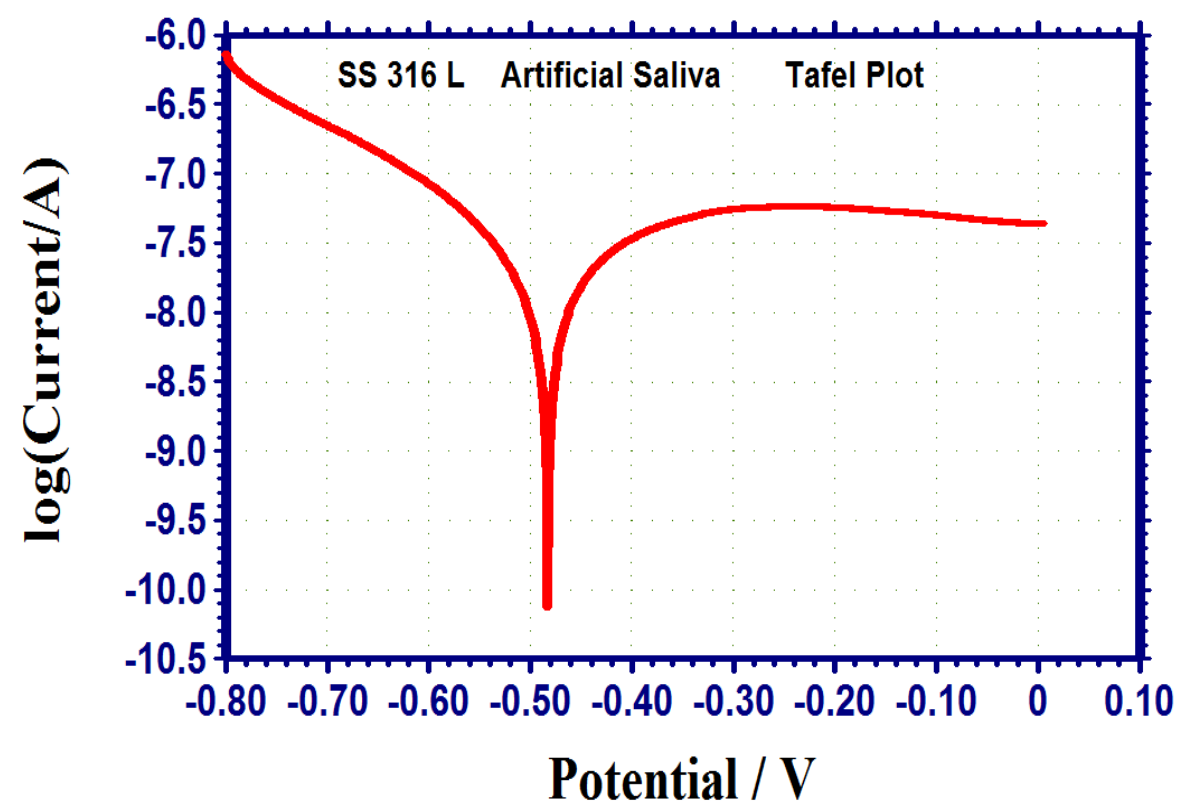

Figure 1. Polarization curve of SS 316L alloy immersed in Artificial Saliva

Slika 1. Polarizaciona kriva legure SS 316L uronjena u veštačku pljuvačku 


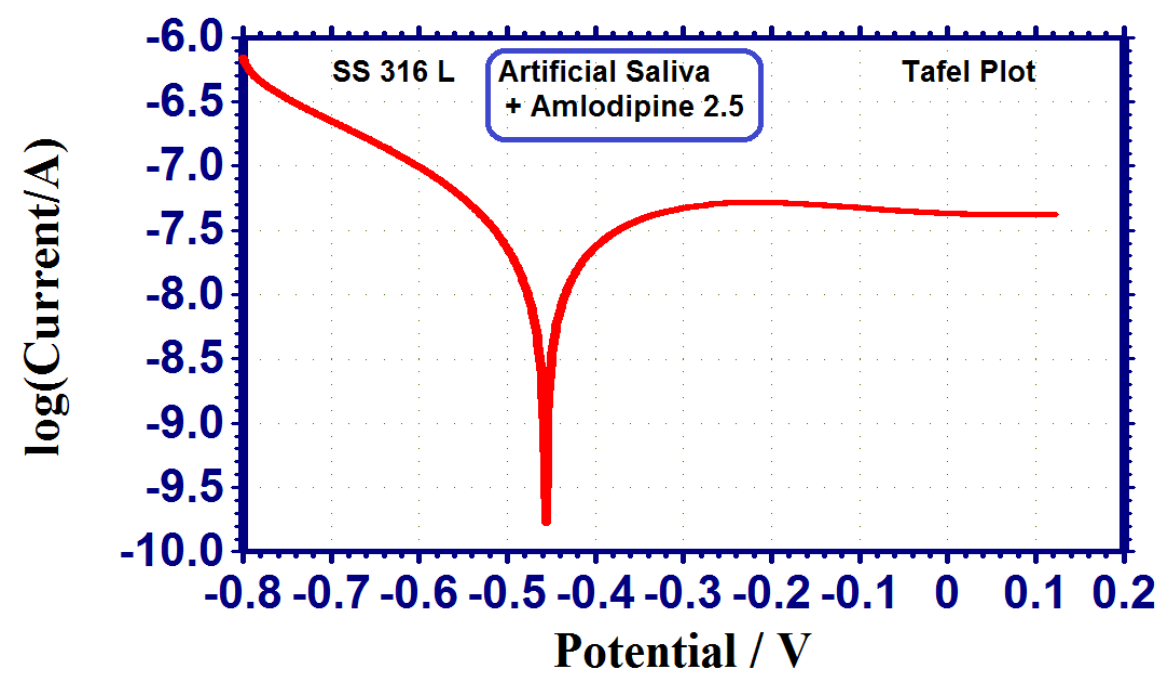

Figure 2. Polarization curve of SS $316 \mathrm{~L}$ alloy immersed in artificial saliva in the presence of Amlodiphine$2.5 \mathrm{mg}$

Slika 2. Polarizaciona kriva legure SS 316L uronjena u veštačku pljuvačku u prisustvu Amlodifina-2,5mg

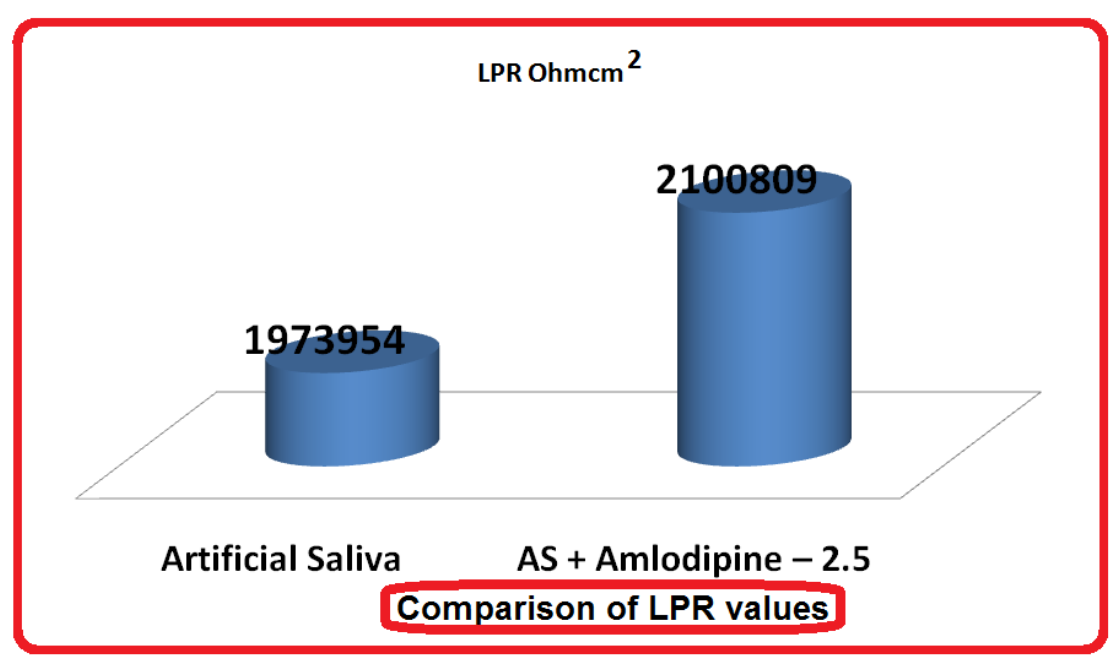

Figure 3. Chart of linear polarization resistance value of SS $316 \mathrm{~L}$ alloy in the absence and presence of Amlodipine- $2.5 \mathrm{mg}$

Slika 3. Grafikon vrednosti linearne polarizacione otpornosti legure SS 316 L u odsustvu i prisustvu Amlodipina-2,5 $\mathrm{mg}$

When SS $316 \mathrm{~L}$ alloy is immersed in artificial saliva, $E_{\text {corr }}$ (corrosion potential) is $-0.483 \mathrm{~V}$ vs SCE. The corrosion current $\left(I_{\text {corr }}\right)$ is $2.245 \times 10^{-8} \mathrm{~A} /$ $\mathrm{cm}^{2}$. Cathodic Tafel slope $\left(b_{c}\right)$ is 6.143 $\mathrm{V} /$ decade.The anodic Tafel slope $\left(b_{a}\right)$ is 3.667 $\mathrm{V} /$ decade. The linear polarization resistance (LPR) is $1973954 \mathrm{ohmcm}^{2}$.

\section{Influence of Amlodiphine-2.5 mg}

When Amlodipine-2.5 mg is added to artificial saliva, the corrosion potential $\left(E_{\text {corr }}\right)$ is $-0.456 \mathrm{~V}$ vs SCE. The corrosion current ( $\left.I_{\text {corr }}\right)$ is $2.190 \times 10^{-8}$ $\mathrm{A} / \mathrm{cm}^{2}$. Cathodic Tafel slope $\left(\mathrm{b}_{\mathrm{c}}\right)$ is 5.835
V/decade.The anodic Tafel slope $\left(b_{a}\right)$ is 3.615 $\mathrm{V} /$ decade.The linear polarization resistance (LPR) is $2100809 \mathrm{ohm} \mathrm{\textrm {cm } ^ { 2 }}$.

It is observed from the Table 1 that when Amlodipine-2.5 $\mathrm{mg}$ is added to AS, the LPR value increases from $1973954 \mathrm{ohm} \mathrm{cm}^{2}$ to $2100809 \mathrm{ohm}$ $\mathrm{cm}^{2}$. The corrosion current decreases from $2.245 \mathrm{x}$ $10^{-8}$ to $2.190 \times 10^{-8} \mathrm{~A} / \mathrm{cm}^{2}$.

This indicates that in presence of Amlodipine$2.5 \mathrm{mg}$, the corrosion resistance of SS 316 alloy in artificial saliva increases. Hence people clipped with orthodontic wire made of SS $316 \mathrm{~L}$ alloy need not hesitate to take Amlodipine- $2.5 \mathrm{mg}$ orally. 


\section{Implication}

Hence people clipped with orthodontic wire made of SS 316L alloy need not hesitate to take Amlodipine-2.5 mg orally.

\section{Analysis of $A C$ impedance spectra}

The AC impedance spectra of SS 316L alloy immersed in AS is given in Table 2. The Nyquist plots are shown in Figure 4 and Figure 5. The Bode plots are shown in Figure 6 and Figure 7. The charge transfer resistance and double layer capacitance values are derived from Nyquist plot. The impedance values are derived from Bode plot.

The charge transfer resistance values of SS $316 \mathrm{~L}$ in artificial saliva in the absence and presence of Amlodipine-2.5 $\mathrm{mg}$ tablet are compared in Table 2 and graphically in Figure 8.

Table 2. Corrosion parameters of SS 316L alloy immersed in Artificial Saliva (AS) in the absence and presence of Amlodipine-2.5 mg obtained by AC impedance spectra

Tabela 2. Parametri korozije legure SS 316L uronjeni u veštačku pljuvačku (AS) u odsustvu i prisustvu Amlodipina-2,5 mg dobijenog pomoću spektra AC impedance

\begin{tabular}{|l|c|c|c|}
\hline \multicolumn{1}{|c|}{ System } & $\begin{array}{c}\mathrm{R}_{\mathrm{t}} \\
\mathrm{Ohmcm}^{2}\end{array}$ & $\begin{array}{c}\mathrm{C}_{\mathrm{dl}} \\
\mathrm{F} / \mathrm{cm}^{2}\end{array}$ & $\begin{array}{c}\text { Impedance } \\
\text { Log(z/ohm })\end{array}$ \\
\hline Artificial Saliva & 320260 & $1.5925 \times 10^{-11}$ & 5.828 \\
\hline AS + amlodipine -2.5 mg (250 ppm) & 470593 & $1.0837 \times 10^{-11}$ & 5.918 \\
\hline
\end{tabular}

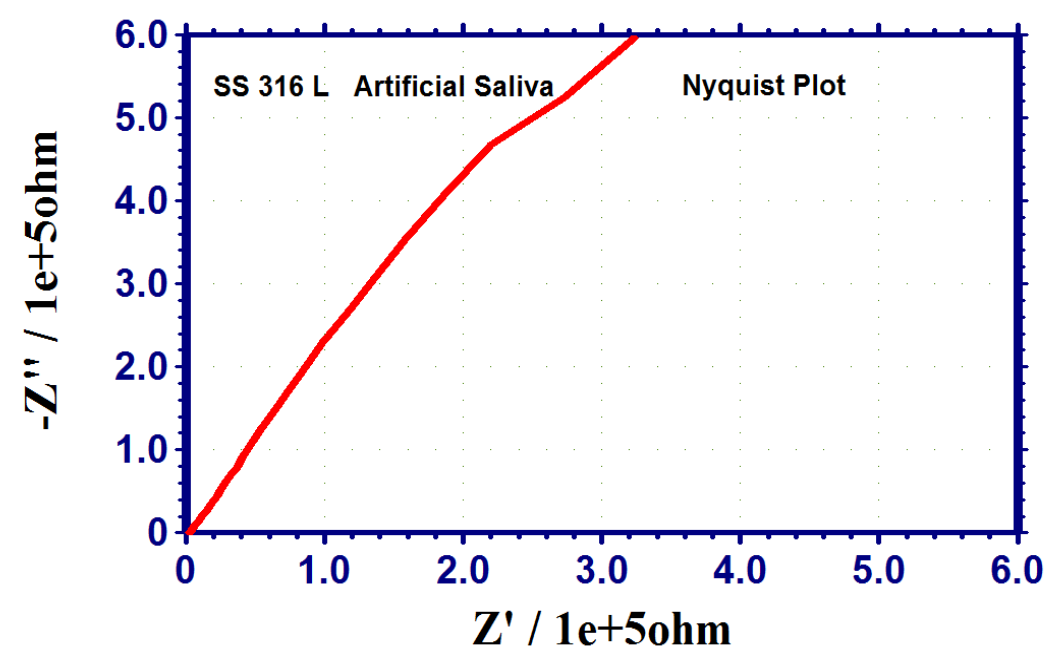

Figure 4. AC impedance spectrum of SS $316 \mathrm{~L}$ alloy immersed in Artificial Saliva Slika 4. Spektar AC impedance legure SS 316 L uronjen u veštačku pljuvačku

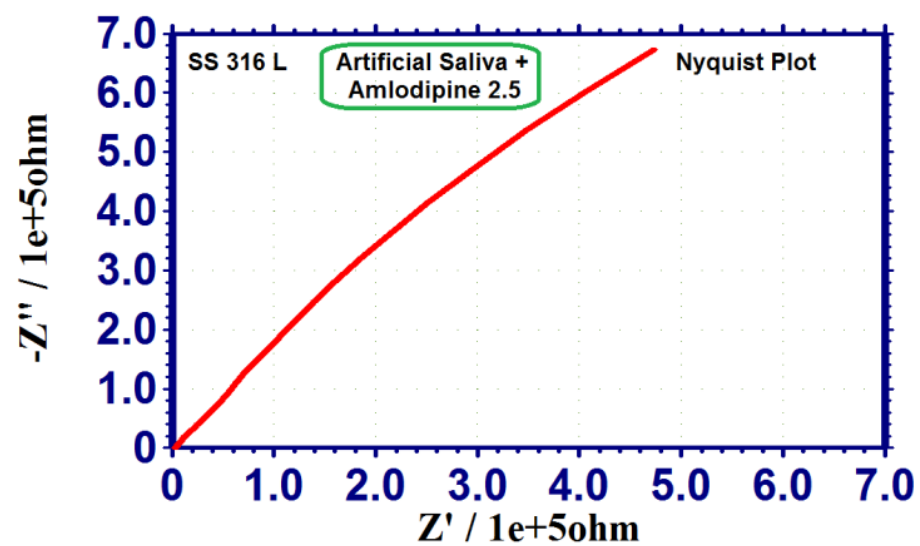

Figure 5. AC impedance spectrum of SS $316 \mathrm{~L}$ alloy immersed in Artificial Saliva in the presence of Amlodipine-2.5 $\mathrm{mg}$

Slika 5. Spektar AC impedance legure SS 316 L uronjen u veštačku pljuvačku u prisustvu Amlodipine-2.5mg 

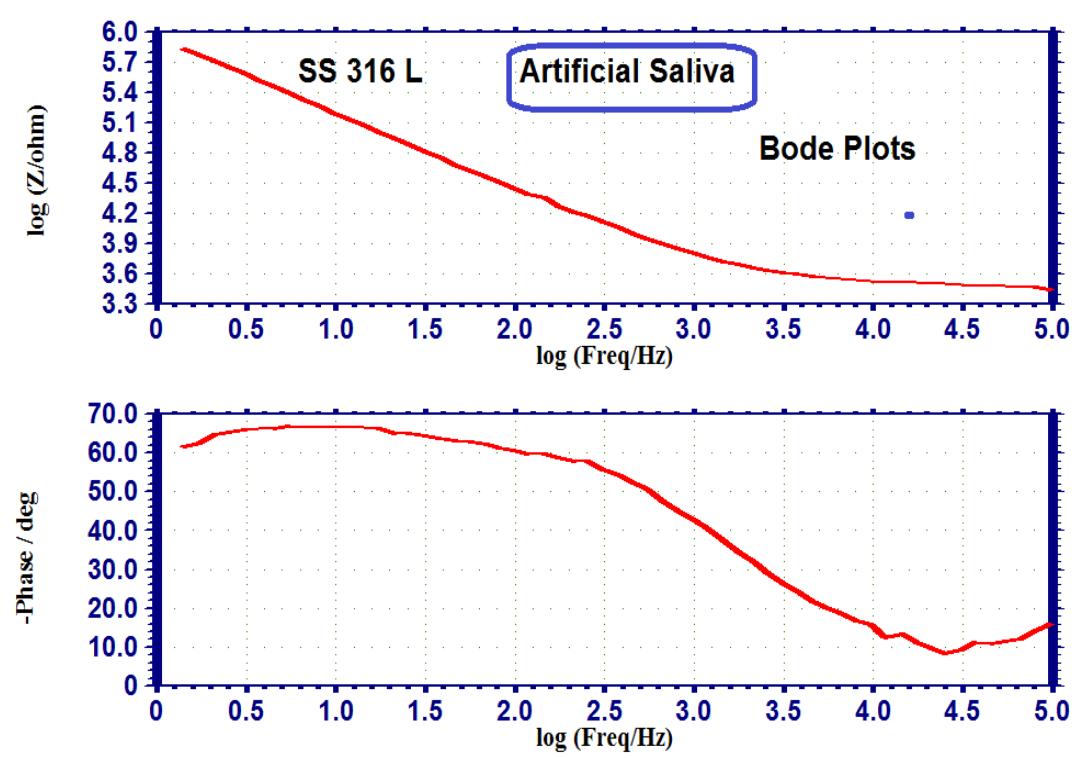

Figure 6. AC impedance spectra of SS 316 L alloy immersed in Artificial Saliva (Bode Plots)

Slika 6. Spektar AC impedance legure SS 316 L uronjeni u veštačku pljuvačku (Bode Plots)
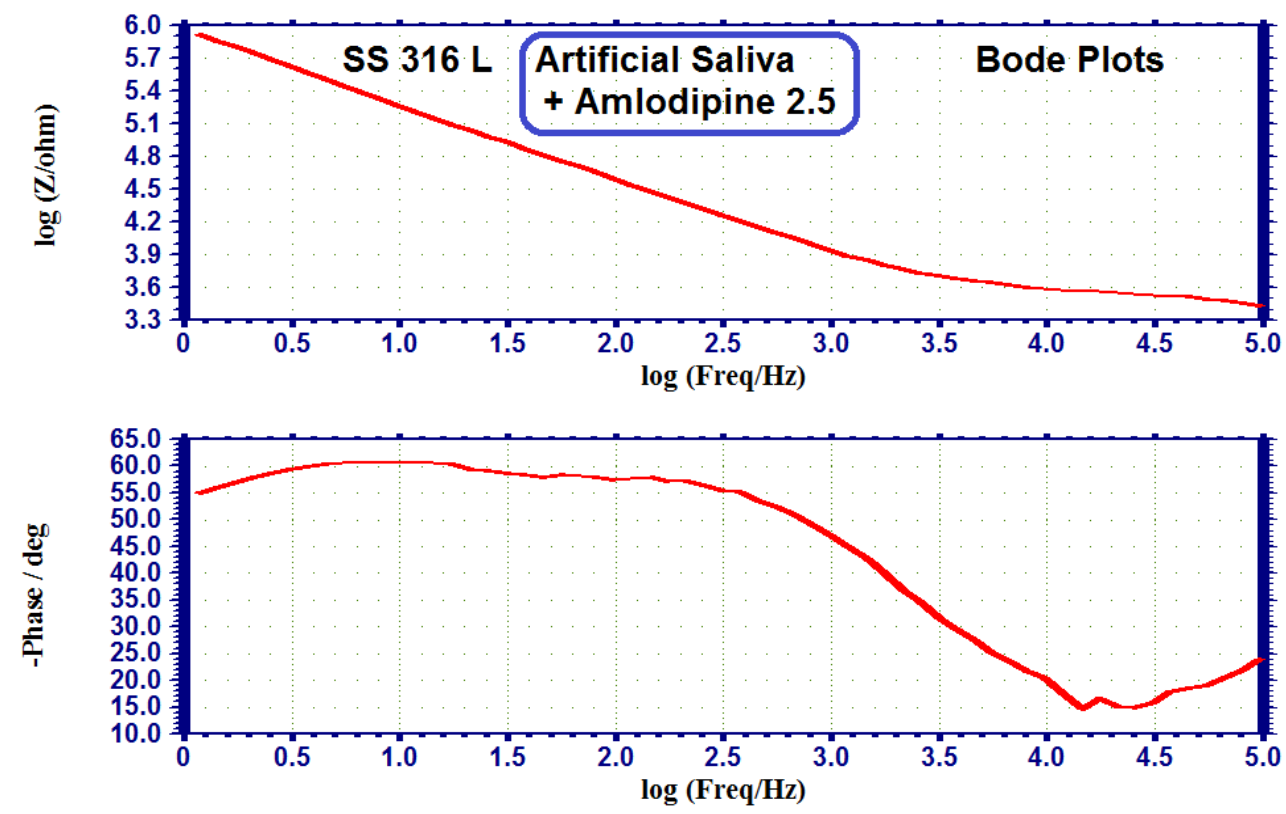

Figure 7. AC impedance spectra of Artificial Saliva in the presence of Amlodipine-2.5 mg (Bode Plots)

Slika 7. Spektar AC impedance veštačke pljuvačke u prisustvu Amlodipina-2,5 mg (Bode Plots)

When SS $316 \mathrm{~L}$ alloy is immersed in artificial saliva, $R_{t}$ (charge transfer resistance) is 320260 ohmcm ${ }^{2}$. $C_{d l}$ (double layer capacitance) is $1.5925 \times 10^{-11} \mathrm{~F} / \mathrm{cm}^{2}$. Impedance is $5.828 \mathrm{log} \mathrm{z} / \mathrm{ohm}$.

\section{Influence of Amlodiphine-2.5 mg}

When Amlodipine-2.5 $\mathrm{mg}$ is added to artificial saliva, the $R_{t}$ (charge transfer resistance) is 470593 ohm $\mathrm{cm}^{2} . \mathrm{C}_{\mathrm{dl}}$ (double layer capacitance) is $1.0837 \times 10^{-11} \mathrm{~F} / \mathrm{cm}^{2}$. Impedance is $5.918 \mathrm{log} \mathrm{z} / \mathrm{ohm}$.
It is observed from the Table 2 that when Amlodipine-2.5 mg is added to AS, the $R_{t}$ Value increases from 320260 to $470593 \mathrm{ohm} \mathrm{cm}^{2}$. Double layer capacitance decreases from $1.5925 \times 10^{-11}$ to $1.0837 \times 10^{-11} \mathrm{~F} / \mathrm{cm}^{2}$.

This indicates that in presence of Amlodipine$2.5 \mathrm{mg}$, the corrosion resistance of SS 316L alloy in artificial saliva increases. Hence people clipped with orthodontic wire made of SS 316L alloy need not hesitate to take Amlodipine- $2.5 \mathrm{mg}$ orally 


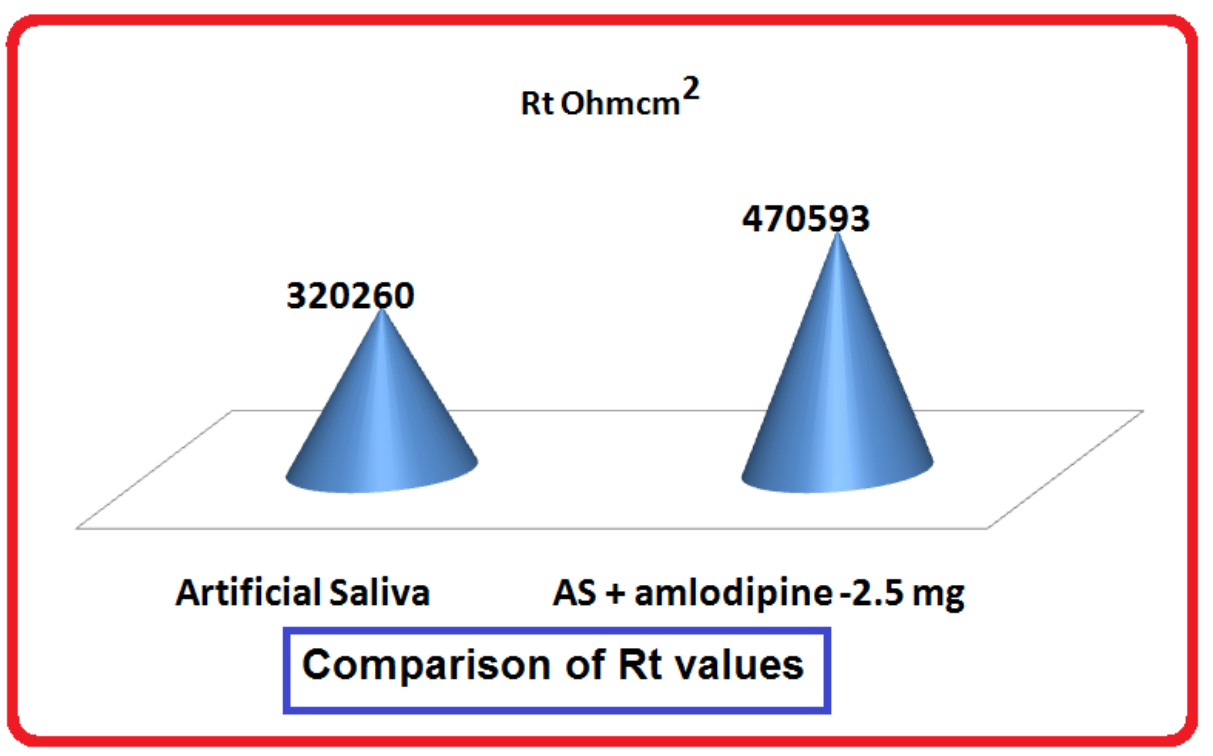

Figure 8. Chart of charge transfer value of SS $316 \mathrm{~L}$ alloy in the absence and presence of Amlodipine-2.5mg

Slika 8. Grafikon vrednosti prenosa naboja legure SS 316 L u odsustvu i prisustvu Amlodipina-2,5 mg

\section{Implication}

Hence people clipped with orthodontic wire made of SS $316 \mathrm{~L}$ alloy need not hesitate to take Amlodipine- $2.5 \mathrm{mg}$ orally.

\section{CONCLUSION}

- The corrosion resistance of SS316L alloy in artificial saliva, in the absence and presence of Amlodipine-2.5 $\mathrm{mg}$ has been evaluated by polarization study and AC impedance spectra.

- Polarisation study reveals that in the presence of Amlodipine-2.5 mg, LPR value increases and corrosion current decreases.

- That is, in presence of Amlodipine-2.5 mg, the corrosion resistance of SS $316 \mathrm{~L}$ alloy in artificial saliva increases.

- AC impedance study reveals that in the presence of Amlodipine-2.5 $\mathrm{mg}, \mathrm{R}_{\mathrm{t}}$ value increases and $\mathrm{C}_{d \mid}$ decreases.

- That is in the presence of Amlodipine-2.5 mg the corrosion resistance of SS $316 \mathrm{~L}$ alloy in AS increases.

- It is concluded that people clipped with orthodontic wire made of SS $316 \mathrm{~L}$ alloy need not hesitate to take Amlodipine- $2.5 \mathrm{mg}$ orally

\section{Acknowledgment}

The authors are thankful to their respective managements for their help and encouragement. Special thanks are due to Rev. Dr.Antony Pushpa Ranjitham (Superior General), Rev. Sr. Thanaseeli Sengole (Asst. General), Rev.Sr.M. Margaret Inbaseeli (College Secretary), Rev. Dr.Pramila
(Principal), Rev. Sr. Gnana Soundari(Provincial) and Mrs J.Antony Justina Mary (Vice Principal) for their Prayer and Blessings.

\section{REFERENCES}

[1] J.Affi, F.Ihsan, H.Fajri, D.Gunawarman (2019) Corrosion Behavior of New Type Titanium Alloy As Candidate for Dental Wires in Artificial Saliva on Fluctuating Temperatures, IOP, Conference Series: Materials Science and Engineering, 547(1), 012022.

[2] A.S.Hammood, A.F.Noor, M.T.Alkhafagy (2017) Effect of heat treatment on corrosion behavior of duplex stainless steel in orthodontic applications, Materials Research Express, 4(12),126506.

[3] A.S.Hammood, A.F.Noor, M.T. Alkhafagy (2017) Evaluation of corrosion behavior in artificial saliva of 2507 and 2205 duplex stainless steel for orthodontic wires before and after heat treatment, Journal of Materials Science: Materials in Medicine, 28(12), 187-195.

[4] A.S.Fouda, W.M. Abo-Elmeaty, H.M.El-Abbasy (2009) Inhibitive action of some 3-thiazinonyl-bicyclo [4.2.0] octene-carboxylate derivatives drugs on the corrosion of SS type 304 in $1 \mathrm{M} \mathrm{HCl}$ solution, Zastita materijala, 50(1), 3-13.

[5] A.S.Fouda, S.M.Rashwan, M.Abdelfatah (2019) Corrosion Inhibition of stainless steel 304 in hydrochloric acid solution using clindamycin antibiotic as Eco-friendly inhibitor, Zastita materijala, 60(1), 3-18.

[6] M.G.Hobbelink, Y.He, J.Xu, R.Stoll, Q.Ye (2015) Synergistic effect of wire bending and salivary $\mathrm{pH}$ on surface properties and mechanical properties of orthodontic stainless steel archwires, Progress in Orthodontics, 16(1), 37-42. 
[7] R.D'Souza, A.Chattree, S.Rajendran (2017) Corrosion resistance of an SS 316L alloy in artificial saliva in presence of a sparkle fresh toothpaste, Portugaliae Electrochimica Acta, 35(6), 339-350.

[8] B.Zerga, A.Attiyibat, M.Sfaira, M.Taleb, B. Hammouti, M. Ebn Touhami, S.Radi, Z.Rais (2010) Effect of some tripodal bipyrazolic compounds on C38 steel corrosion in hydrochloric acid solution, J. Appl. Electrochem., 40, 1575-1582.

[9] A.S.Fouda, F.I.El-Dossoki, E.A.Sello (2019) Esomeprazole Magnesium Trihydrate drug as a potential non-toxic corrosion inhibitor for mild steel in acidic media, Zastita materijala, 60(3), 245-259.

[10] V.J.Pulikkottil, S.Chidambaram, P.U.Bejoy, P.Paul, M.Rishad (2016) Corrosion resistance of stainless steel, nickel-titanium, titanium molybdenum alloy, and ion-implanted titanium molybdenum alloy archwires in acidic fluoride-containing artificial saliva: An in vitro study, Journal of Pharmacy and Bioallied Sciences, 8, S96-S99.

[11] M.K.EI Kouifat, Y.El Hamdouni, B.Ouaki, S.El Hajjaji (2018) Fretting-corrosion of orthodontic archwire/bracket contacts in saliva environment, World Journal of Dentistry, 9(5), 387-393.

[12] P.Osak, B.Łosiewicz (2018) EIS Study on Interfacial Properties of Passivated Nitinol Orthodontic Wire in Saliva Modified with Eludril Mouthwash, Protection of Metals and Physical Chemistry of Surfaces, 54(4),680- 688.

[13] K.Nanjundan, G.Vimala (2016) Evaluation of frictional resistance and surface characteristics after immersion of orthodontic brackets and wire in different chemical solutions: A comparative in vitro study, Indian Journal of Dental Research, 27(5), 513-520.

[14] L.Gölz, A.C.Knickenberg, L.Keilig, A.Jäger, C. Bourauel (2016) Nickel ion concentrations in the saliva of patients treated with self-ligating fixed appliances: a prospective cohort study, Journal of Orofacial Orthopedics, 77(2), 85-93.

[15] https://www.healthline.com/health/amlodipine/oraltablet, 22.03.2018.

[16] S. Rajendran, M. Agasta, R.B.Devi, B.S.Devi, K. Rajam, J.Jeyasundari (2009) Corrosion inhibition by an aqueous extract of Henna leaves (Lawsonia Inermis L),Zaštita materijala, 50(2), 77-84.

[17] S.Rajendran, M.K.Devi, A.P.P.Regis, A.J.Amalraj, J.Jeyasundari (2009) Electroplating using environmental friendly garlic extract: A case study, Zastita materijala, 50(3), 131-140.

[18] S. Rajendran, P.Sumithra, S.B.Devi, J.Jeyasundari (2009) Corrosion inhibition by spirulina, Zaštita materijala, 50(4), 223-226.

[19] S.Rajendran, M.Kanagamani, M.Sivakalaivani, J. Jeyasundari (2008) Corrosion behaviour of carbon steel in presence of $\mathrm{Cu}[2+]$ ions and citrate ions, Zaštita materijala, 49(4), 19-27.

[20] AJ Selvi, S Rajendran, J Jeyasundari, 2009, Analysis of nano film by atomic force microscopy, Zaštita materijala, 50 (2), 91-98

[21] S.Rajendran, V.Sribharathy, A.Krishnaveni, J. Jeyasundari, J.Sathiyabama (2011) Inhibition effect of self assembled films formed by adipic acid molecules on carbon steel surface, Zaštita materijala, 52(3), 163-172.

\title{
IZVOD
}

\section{ELEKTROHEMIJSKA ISPITIVANJA OTPORNOSTI NA KOROZIJU ORTODONTSKE ŽICE IZRAĐENE OD LEGURE SS 316L U VEŠTAČKOJ SLINI U PRISUSTVU AMLODIPINSKE TABLETE}

\begin{abstract}
Otpornost na koroziju legure SS 316L u veštačkoj slini, u odsustvu i prisustvu Amlodifina-2,5 mg, procenjena je polarizacijskim istraživanjem i spektrima AC impedance. Polarizaciona studija otkriva da se u prisustvu Amlodipina-2,5mg povećava LPR vrednost i smanjuje se struja korozije. U prisustvu Amlodipina-2,5mg povećava se korozijska otpornost legure SS 316L u veštačkoj slini. Ispitivanje AC impedance pokazuje se da u prisustvu Amlodipina-2,5mg Rt vrednost raste i Cdl opada. U prisustvu Amlodipina-2,5mg povećava se korozijska otpornost legure SS 316L u AS. Iz ove studije je zaključeno da ljudi koji su vezani za ortodontsku žicu izrađenu od legura SS $316 \mathrm{~L} \mathrm{ne}$ moraju se ustručavati da uzimaju Amlodipin-2,5mg oralno.
\end{abstract}

Ključne reči: SS 316L legura, Amlodipin-2,5mg, elektrohemijska ispitivanja, veštačka pljuvačka

\author{
Short communication \\ Rad primljen: 10. 04. 2020. \\ Rad korigovan: 24. 05. 2020. \\ Rad prihvaćen: 02. 06. 2020. \\ Rad je dostupan na sajtu: www.idk.org.rs/casopis
}

\footnotetext{
(c) 2020 Authors. Published by Engineering Society for Corrosion. This article is an open access article distributed under the terms and conditions of the Creative Commons Attribution 4.0 International license (https://creativecommons.org/licenses/by/4.0/)
} 